Research Article

\title{
EVALUATION PERFORMANCE COVID-19 TASIKMALAYA TASK UNIT
}

\author{
Danial Kusumah *, Dede Aji Mardani \\ STAI Tasikmalaya
}

\author{
Article history: \\ Submission 16 June 2021 \\ Revised 22 June 2021 \\ Accepted 30 June 2021 \\ *Corresponding author: \\ E-mail: \\ danialkusumah@gmail.com
}

\begin{abstract}
The role of the Covid-19 Task Force determines the effectiveness of handling the pandemic in Tasikmalaya City. Performance evaluation is an instrument to measure the gap between the established policies and the resulting achievements. The analytical method in this study uses a literature study through a qualitative approach. By using the indicators of transparency, participation, responsiveness, and accountability, it was found that the Covid-19 Task Force has shown good performance in efforts to accelerate the handling of the corona virus in the City of Tasikmalaya. However, continuous performance improvement is needed to be able to significantly reduce the number of positive cases.
\end{abstract}

Keywords: Task Force, Performance, Covid-19

\section{Introduction}

On March 11, 2020, the 2019 Coronavirus (Covid-19) outbreak was declared a pandemic by the world health organization (Jones, 2020). The rate of spread and transmission of the corona virus is more aggressive than the previous generation of similar virus variants. This forces affected countries to develop integrated policies with a primary focus on health, education, and the economy.

The Ministry of Health (Kemenkes) has set guidelines for large-scale social restrictions (PSBB). At the technical level, the Ministry of Health issues a circular regarding health protocols that must be applied when carrying out social activities. In the field of education, changing face-to-face teaching and learning activities with online distance learning. In the economic field, the government disburses cash and non-cash social assistance to avoid prolonged economic turmoil that can cause a recession (Mufida, 2020).

Initially, to deal with the Covid-19 invasion, the first policy taken by the government was to form a special unit called the Task Force for the Acceleration of Handling Corona Virus Disease 2019 (Covid-19) through Presidential Decree No. 7 of 2020. This step is taken so that the emergency handling of the disease outbreak caused by the corona virus can be carried out in a planned, measured, systematic, integrative and synergistic manner. The main objectives of the establishment of this task force are strengthening national resilience in the health sector, accelerating the handling of Covid-19 by strengthening synergy between government agencies, suppressing the growth rate of spread, and mitigating disasters through prevention, detection, and response movements (Katharina, 2020).

How to cite:

Kusumah, D. \& Mardani, D. A. (2021). Evaluation performance Covid-19 Tasikmalaya task unit. Indonesian Journal of

Social Science Research, 2(1), 44 - 51. doi:10.11594/ijssr.02.01.07 
Operationalization of work is carried out in a structured and tiered manner, starting from the center, regions to the smallest government level at the RT/RW level. A number of parties appreciate the government's tactical steps to deal with the massive transmission of the virus, which until now has been declared to be spread in all provinces in Indonesia.

Not a few parties are still questioning the performance of the Covid-19 Task Force. Confirmed from several reports published by several survey institutions. The Indonesian Political Indicator (2020) reports that in general the public is satisfied with the government's performance at $56.4 \%$. However, as many as $31.3 \%$ of the public perception was dissatisfied with the efforts of the Covid-19 Task Force. Another survey agency stated that $57.8 \%$ of the public were satisfied with the government's performance in dealing with the Covid-19 pandemic. However, there are $40 \%$ of respondents who say they are not satisfied with the performance so far (Wijaya, 2020).

The indicators used to measure the level of community satisfaction with the performance of the Covid-19 Task Force include: health facilities, accountability and transparency of information, data accuracy, and distribution of social assistance. The high level of community dissatisfaction, of course, cannot be eliminated by a higher proportion of satisfaction levels quantitatively. The government is expected to improve its performance in order to accelerate the handling of the corona virus outbreak in Indonesia.

The complexity of the problems caused by Covid-19 has implications for government performance. This study will discuss the evaluation of the performance of the Task Force for the Acceleration of Handling Covid19. In order to be more focused, the research will be conducted within the Tasikmalaya City Government. Therefore, the nomenclature is adjusted to the work unit at the Regency/City level, namely the Covid-19 Handling Task Force. The results of the study are expected to be input in order to improve the performance of the Tasikmalaya City Covid-19 Handling Task Force in the era of adaptation to new habits.

\section{Literatur Review}

A. The Urgency of Performance Evaluation

Performance is an acronym for work energy kinetics which has the equivalent of the word performance in English. Performance is the output obtained from indicators or functions of a job or profession within a certain period of time (Wirawan, 2013). (Makawi et al., 2015) defines performance as a description of the acquisition of the implementation of an activity or policy in achieving the organization's vision, mission, goals, and objectives contained in the strategic plan. While PP No. 8 of 2006 explains that performance is the output or result of an activity or program that is to be or has been achieved in connection with the use of a budget with measurable quantity and quality. Therefore, performance describes the results or work achievements that can be achieved by individuals, work units, and or an organization in a certain time span in accordance with their main tasks and functions in an effort to achieve normative goals while still observing morals and ethics.

To measure the extent of HR performance, the achievement of the targets that have been set, the comparison between inputs and outputs, it is necessary to carry out an organic and continuous evaluation of a series of work processes over a certain period of time. Evaluation is a strategic controlling tool for the implementation of an activity or program. Performance evaluation is a standardized and structured system used to assess, measure, and influence dimensions related to behavior, work, and outcomes, including absenteeism levels (Rozalia, 2015).

According to Mardiasmo (Mardiasmo, 2011) performance evaluation has benefits: firstly it forms an understanding of the minimum assessment standards used for evaluating organizational performance. Second, develop directions to achieve predetermined performance targets. Third, monitoring performance achievements and comparing them with performance targets and taking corrective actions within the framework of performance improvement. Fourth, it becomes the basis for objective considerations in providing rewards and punishments for work results. Fifth, as a 
means of vertical communication (leadership with subordinates) to improve management performance. Sixth, helping to understand the flow of the organization's activity process. Seventh, ensure the objectivity of taking.

\section{B. Public Service Standards}

Before preparing public service standards, it is necessary to understand the service paradigm first. The service paradigm determines how the service design, the perspective of the service object, the role of the government, bureaucracy and other things will have direct and indirect implications for the quality of public services held. (Dwimawanti, 2004).

In a paradigmatic context, the government must be able to position itself as a formulator, implementer, and policy controller. Everyc. decision making uses the assumption of the blade. Thus, policies will become signs, work tools, as well as control tools in the implementtation of government activities. The government is not a ruler, nor is the community an object. The ideal pattern of the relationship between the bureaucracy and the community is contractual. The community gives a mandate to the bureaucracy to organize government and has the right to get services. Thus, public service is not a gift from the government but a right as a citizen. In order for public services to meet the elements of optimum quality and in accordance with the development objectives outlined in the constitution, service providers are required to formulate service standards as an evaluative instrument to measure qualitative and quantitative achievements.

Law No. 25 of 2009 defines public service as an activity or series of activities in the context of fulfilling service needs in accordance with laws and regulations for every citizen and resident of goods, services, and/or administrative services provided by public service providers. (Tome, 2012). While the service standard is a benchmark that is used as a reference for assessing service quality as a commitment or promise from the service provider to customers to provide quality services.

To realize the effectiveness of public services, service delivery must meet the following service standard principles (Permenpan No. 20 of 2006), including:
1. Consensus, understanding and mutual agreement between the leadership and staff of the service unit;

2. Concrete, real and clear to be implemented;

3. Open, open to get input and suggestions for improvement;

4. Accountability, the rules and implementation of service standards can be accounted for in a real way to stakeholders;

5. Have a deadline for delivery, commitment to punctuality for the achievement of everything regulated in service standards;

6. Continuous, continuous improvement of service standards in accordance with developments and demands for improving service quality.

\section{Dimensions and Indicators of Public Services}

Providing services to the public (community) is one of the main agendas in the administration of government. To guarantee a good and democratic state system, the government must accommodate the inherent democratic values, namely being transparent, participatory, responsive, and accountable.(Silalahi, 2015).

Public service transparency reflects the openness of the state apparatus to the public in implementing government programs. The intended openness is the freedom of citizens to express their opinions as well as the availability and ease of access to information. Providing information is not only related to access, it is also related to active publications and timeliness. Information that is outdated or late, has no significant benefit or is even useless. The provision of information to the public is carried out in a balanced or proportional manner, between the need for openness and access and the need for confidentiality and protection. Transparency effectively enhances institutional credibility and legitimacy, efficiently controls resource allocation and minimizes.

Community participation is the key to the success of government programs. Therefore, in formulating policies, the government should involve the community in the drafting process, because the community is both the actor and the beneficiary of the policy. The purpose of community participation, among others, is intended as a process of community 
empowerment ((Schiavo-Campo \& Sundaram, 2000). Konsep partisipasi The concept of community participation shows that there are two parties that play a role. The parties involved (government) and the parties involved or participants (society). The role of the parties can be interpreted as providing information to each other, listening and absorbing aspirations, and negotiating.

National public participation associations put forward the core value of public participation (Prasojo, 2004), as follows:

1. Every decision/policy will have an impact on people's lives, so participants must be able to express their opinions;

2. Through the process of participation there is a communication of desires and fulfillment of the process needs of all participants;

3. Provide participants with the information they need to participate meaningfully;

4. Discuss with participants how their input will affect the decision;

5. Invite participants to identify public issues that will affect economic, social, political, cultural, environmental, and psychological life that will be associated through alternative action pathways.

Responsiveness of public services refers to the responsiveness of the government to the community for various dynamics that occur as a result of the implementation of government activities (Syafri, 2015). A democratic country runs a government system that is responsive to the preferences of the people. This illustrates the active interaction between the government and the people. The dimension of responsiveness quality in public services lies in the speed (responsiveness) and accuracy of service to meet the wishes of the community. Thus, responsiveness can be measured by the speed in identifying community needs and accuracy (accuracy) in providing solutions to various community needs by formulating them in public decisions/policies. Response speed refers to the waiting time span between public requests for public services and service actions provided by the government.

Public accountability is defined as the government's obligation to convey accountability to the public by explaining and responding to actions they take or do not take (Armstrong \& Baron, 2005). The implementtation of services must be in accordance with the interests of the community and applicable regulations.

There are 5 (five) dimensions of accountability according to (Mahmudi, 2015): 1) Legal accountability and honesty, namely guaranteeing the compliance of public service providers in complying with applicable norms; 2) Managerial accountability, which is accountable organizational governance effectively and efficiently; 3) Program accountability, namely consistency between program planning and implementation; 4) Policy accountability, namely the government's accountability for the impact of the planned program; and 5) Financial accountability, namely public institutions must avoid waste and misuse of budgets, and prepare financial reports as a form of administrative responsibility.

\section{Method}

The method used was a qualitative approach. The technique used by researcher was a survey of academic literature to obtain the concepts relevant to the study of zakat and the community economic welfare. The technique of collecting the data was through searching various sources and literature, both from government documents as well as printed and electronic mass media reports, journals, and books related to zakat literature and the community economic welfare. The secondary data were processed and described in the form of a narrative according to the data needs. Furthermore, the data analysis process was carried out based on the theory and concept of zakat, and then followed by the data interpretation process.

To analyze the performance of the Covid-19 Handling Task Force in this study, a literature study with a qualitative approach was used. This method works through the process of finding out the problem, searching for data and facts, contextual elaboration, compiling alternative solutions and recommendation (Darmalaksana, 2020).

The locus of this research is the Tasikmalaya City Government c.q the Covid-19 Handling Task Force. Data was collected by using 
interviews, field observations, and documentation. The data analysis technique uses data reduction. Data triangulation is used to measure the truth of the data through the synthesis method.

\section{Discussion}

\section{A. Transparency}

Transparency guarantees the right of access for each individual to obtain information on the implementation of government activities, namely information on policy formulation, policy formulation processes, policy implementtation, and results achieved (Bappenas and Ministry of Home Affairs, 2002). Through the disclosure of information to the public, it is expected to produce policies based on public preferences, increase tolerance, and healthy political dynamics.

(Taufik \& Bandi, 2015) stated that there are 4 (four) indicators in measuring the transparency of public services, namely the provision of clear information, easy access to information, compiling a complaint mechanism if there are rules that are violated or reporting channels for an incident, and increasing the flow of information through collaboration with the mass media and non-governmental organizations. government.

Information about Covid-19 in the City of Tasikmalaya is provided by the Covid-19 Task Force through various channels such as websites, social media (instagram, facebook, twitter), agency-based command posts. The mikotas.tasikmalayakota.go.id page is the main portal that presents various types of information in the form of graphs, tables, descriptions, and various legal products relevant to the handling of Covid-19. The Instagram account of the Communication and Informatics Service was strengthened, which presented data in the form of infographics as well as news of events and handling related to the corona outbreak in the City of Tasikmalaya.

Not only providing data and information, the government also opens online and offline complaint channels. To report cases in the field, an online complaint feature is provided on the website and social media networks. Offline complaints are more interactive, under the responsibility of the relevant agencies that serve the Covid-19 problem, such as the Regional Disaster Management Agency (BPBD), the Health Service, RSUD, and others. The mass media are also involved to strengthen and expand the flow of information as well as educational media. This entity participates in updating the development of Covid-19 cases, implementing vaccinations, and education on health protocols.

In collaboration with the Hoaks Saber Team of the West Java Provincial Government, the Covid-19 Handling Task Force seeks to ward off hoax attacks by verifying information that is not based on facts circulating in the community. Verification of information is carried out through the process of tracing, confirming, compiling, and processing data through credible and actual sources or references.

\section{B. Participation}

The agenda-setting analysis is the entry point for the overall policy formulation process. This process invites the community to play an active role in exploring potential development issues. The public is given an open space to participate in policy formulation. This can develop alternative paradigms of decision making by placing public policy in a balanced way between infrastructure and political superstructure. Public participation requires community contributions in the form of thoughts, energy and funds, as well as participation in maintaining development outcomes (Meisner et al., 2003).

In the midst of the pagebluk period which is still high in tension, the government is forced to implement the adaptation of new habits. Public involvement as a subject becomes the main indicator of success. The Tasikmalaya City Government involved all elements of the community to discuss the strategic meeting for handling Covid-19. Physically, the community is volunteering with the Covid-19 Handling Task Force in charge of conducting mass health detection, transferring knowledge of health protocols to the field, evacuating positive case patients by medical volunteers, controlling social activities, and so on. One of these activities was carried out in response to the stipulation of Mayor Regulation No. 19 of 2020 concerning the Enforcement of Proportionately 
Large-Scale Social Restrictions in the City of Tasikmalaya.

\section{Responsibility}

Responsiveness refers to the responsiveness of the bureaucracy in handling public complaints, the attitude of the apparatus in responding to complaints, the use of public complaints as a reference for improving public services, and government actions in providing services and placing service users in the applicable service system. (Dwiyanto, 2002)

In order to realize effective services in the City of Tasikmalaya, the government stipulates the Mayor of Tasikmalaya Regulation Number 37 of 2019 concerning Guidelines for Managing Public Complaints About Public Services. The public can submit their complaints through the People's Online Aspiration and Complaints Service (LAPOR) application which can be accessed on the lapor.go.id website.

To deal with health problems, the City Government (Pemkot) of Tasikmalaya provides a Public Safety Center (PSC) 119 Si Cetar (Tasik Rapid Emergency Response) post which functions as a 24-hour health emergency service. This service can be accessed through the hotline number 119/08112113119. In addition to the post, Si Cetar facilitates free ambulances supported by medical equipment such as oxygen cylinders, direct current shocks for the heart, stretchers and long speedboats, blood pressure monitors, and emergency kit bags equipped with oxygen.

The Tasikmalaya City Government has prepared health facilities or supporting infrastructure specifically for the acceleration of handling Covid-19 in the form of isolation rooms/rooms, laboratories, mass test kits, ambulances, PPE, and ventilators. For isolation rooms, optimizing regional and private hospitals, such as hospitals. Dr. Soekardjo, RS. Jasa Kartini, RS. Tasik Medika Citratama (TMC), and RS. Dewi Sartika. Several public facilities have been transformed into places of isolation as a consequence of the escalation of positive cases that has not been sloping, namely the Crown Hotel and Unsil Rusunawa. In addition to utilizing facilities in hospitals, the government is increasing the utility of the Regional Health Laboratory (Labkesda) for sample testing/ detection of the corona virus. Meanwhile, for the evacuation of patients and victims who died due to Covid-19 infection, 3 (three) ambulances and 1 (one) hearse were provided. As for the need for medical equipment and equipment, apart from being supported by the APBD, the community also actively contributes to various health supports, including Personal Protective Equipment (PPE), masks, and face shields. Assistance is provided by the community directly or through government facilitation, both individually and institutionally.

\section{Akuntabilitas}

A set of laws and regulations requires each government agency to be responsible for the implementation of its main tasks and functions as well as the authority to manage resources based on a strategic plan determined by each agency. The accountability is in the form of a report submitted to the leadership, supervisory institutions and accountability assessors, and finally submitted to the President as the head of government. The report describes the performance of the relevant government agencies through the Government Agency Performance Accountability System 1 .

The implementation of government accountability in Tasikmalaya City is based on Mayor Regulation Number 10 of 2016 concerning Guidelines for Evaluation of Government Agency Performance Account-ability (AKIP). The scope of AKIP Evaluation includes evaluation of performance planning and performance agreements including implementation of performance-based budgeting, program and activity implementation, performance measurement, performance reporting, internal evaluation and performance achievement.

So far, the Covid-19 Task Force has demonstrated integrity and compliance with applicable regulations while carrying out its duties. Each of their behavior or actions refers to a predetermined procedure. There were no indications of abuse of authority in the process of handling the Covid-19 handling. A number of complaint portals provided by the government do not receive reports of activities or actions that violate procedures (protap). Although there are several complaints regarding the proportionality of the distribution of social 
assistance (bansos), this cannot be used as a measure of deviation, because the justification for receiving social assistance is mostly within the authority of the central and provincial governments.

The synergy between implementing agencies is going well. All implementing elements are involved in the planning, action, and evaluation processes. The implementation of the Tasikmalaya City Covid-19 Task Force consists of elements of the Indonesian National Army (TNI) represented by Kodim 0612, elements of the State Police of the Republic of Indonesia represented by the Tasikmalaya City Police, elements of the Regional Government by relevant agencies and agencies, and other elements that are within the City Government of Tasikmalaya

On March 19, 2020, Kodim 0612 together with BPBD gave directions to dozens of the Covid-19 Task Force to educate the public regarding joint steps to deal with the spread of the corona virus. crowds caused by the celebration of the new year (republika.co.id, 28/12). Tasikmalaya Police together with Kodim 0612, Satpol PP, and other agencies held a judicial operation in law enforcement discipline of health protocols at 20 (twenty) points of social activity. The series of news shows that all elements are present collaborating to realize the acceleration of overcoming the Covid-19 outbreak.

Regarding the use of funds to accelerate the handling of Covid-19, there has been no publication of financial accountability reports either in writing or through press conferences conducted by the Tasikmalaya City Government. This can reduce the level of public confidence in the efficiency of budget allocations and the potential for misuse of funds.

\section{Conclusions}

Based on the results of the study, this study provides a number of notes related to the evaluation of the performance of the Tasikmalaya City Covid-19 Handling Task Force. Evaluation analysis refers to 4 (four) dimensions of public service, namely transparency, participation, responsiveness, and accountability.
In general, the Covid-19 Task Force has met the appropriate standards for service performance to the public. However, efforts are needed to improve the quality of work towards maturity in the era of adapting new habits. First, in the aspect of transparency, the accuracy of information conveyed to the public must be improved, presented in real time, and distributed directly to the lowest levels of government (RT/RW).

Second, on the aspect of participation. The government is the maker and bridge of policy communication. People with different backgrounds need continuous education to comply with government instructions and appeals. In addition to aiming to suppress the spread of the virus, it is the government's obligation to protect public safety.

Third, on the aspect of responsiveness. The trend of positive cases has not shown a sloping direction. Therefore, it is necessary to consider adding an isolation room to avoid waiting list queues, especially for patients with serious symptoms. The projection of the need for supporting infrastructure for health services can utilize an integrated health information system.

Fourth, on the aspect of accountability. In practice, the Covid-19 Task Force receives funding allocations from the APBD and other legal and non-binding sources in accordance with the provisions of laws and regulations. A number of assistance also came from several elements of society. The government is obliged to strive for the publication of accountability for the use of the budget through factual and credible financial reports. Transparency of financial reports can increase public confidence in the Tasikmalaya City Government, especially the Covid-19 Handling Task Force.

\section{Reference:}

Armstrong, M., \& Baron, A. (2005). Managing performance: performance management in action. CIPD publishing.

Darmalaksana, W. (2020). Metode Penelitian Kualitatif Studi Pustaka dan Studi Lapangan. Pre-Print Digital Library UIN Sunan Gunung http://digilib.uinsgd.ac.id/32855/

Dwimawanti, I. (2004). Kualitas Pelayanan Publik. Jurnal Ilmu Administrasi Dan Kebijakan Publik. 
Dwiyanto, D. (2002). Metode Kualitatif: Penerapannya dalam Penelitian. In Diakses dari: https://www. academia. edu/download .... academia.edu. https://www.academia.edu/download/45555425/ metode kualitatif penerapannya dalam penelitian. $\underline{\mathrm{pdf}}$

Jones, D. S. (2020). History in a crisis-lessons for Covid19. New England Journal of Medicine, 382(18), 16811683.

Katharina, R. (2020). Relasi Pemerintah PusatPemerintah Daerah Dalam Penanganan COVID-19. INFO Singkat, 12(5), 25-30.

Mahmudi, A. A. (2015). Sistem Informasi Penilaian Kinerja Dosen dan Karyawan Berbasis Web. Jurnal Surya Informatika: Membangun Informasi Dan Profesionalisme, 1(1).

Makawi, U., Normajatun, N., \& Haliq, A. (2015). Analisis pengaruh kompetensi terhadap kinerja pegawai dinas perindustrian dan perdagangan kota banjarmasin. AL-ULUM: Jurnal Ilmu Sosial Dan Humaniora, 1(1).

Mardiasmo. (2011). Perpajakan. Perpajakan, 34.

Meisner, C. A., Sufian, A., Baksh, E., O’Donoghue, M. S., Razzaque, M. A., \& Shaha, N. K. (2003). Whole family training and adoption of innovations in wheatproducing households in Bangladesh. The Journal of Agricultural Education and Extension, 9(4), 165175.

Mufida, A. (2020). Polemik Pemberian Bantuan Sosial Di Tengah Pandemic Covid 19. 'ADALAH, 4(1).
Prasojo, E. (2004). People and Society Empowerment: Perspektif Membangun Partisipasi Publik. Jurnal Ilmiah Administrasi Publik, 4(2), 10-24.

Rozalia, N. A. (2015). Pengaruh Motivasi Kerja dan Disiplin Kerja Terhadap Kinerja Karyawan (Studi Kasus Pada Karyawan PT. Pattindo Malang). Jurnal Administrasi Bisnis, 26(2).

Schiavo-Campo, S., \& Sundaram, P. (2000). To serve and to preserve: Improving public administration in a competitive world. Asian Development Bank.

Silalahi, S. (2015). Pengaruh Kualitas Pelayanan Perpajakan Terhadap Kepuasan Wajib Pajak, Kepatuhan Wajib Pajak dan Penerimaan Pajak (Studi Pada Kantor Pelayanan Pajak Madya Malang). Jurnal Mahasiswa Perpajakan, 4(1).

Taufik, M. G., \& Bandi, B. (2015). Karakteristik pemerintah daerah karakteristik kepala daerah, karakteristik inspektorat daerah dan ketepatan waktu penyampaian laporan keuangan pemerintah daerah Indonesia. Jurnal Akuntansi Dan Bisnis, 15(1), 65-73.

Tome, A. H. (2012). Reformasi Birokrasi Dalam Rangka Mewujudkan Good Governance Ditinjau Dari Peraturan Menteri Pemberdayaan Aparatur Negara dan Reformasi Birokrasi Nomor 20 Tahun 2010. Jurnal Hukum Unsrat, 20(3), 132-147.

Wijaya, V. (2020). Evaluasi Kinerja Gugus Tugas Percepatan Penanganan Covid-19. Policy.

Wirawan, I. (2013). Teori-teori Sosial dalam Tiga Paradigma Fakta Sosial, Definisi Sosial dan Perilaku Sosial. Kencana Prenadamedia Group 